\title{
Kinetic Evaluation of the Uptake and Decomposition of Pesticides by Algae (1)
}

\author{
Toshiie Nakamura and Kazuo Mochida \\ Department of Environmental Sciences, Shimane University, \\ Nishikawatsu-cho, Matsue 690, Japan
}

(Received July 30, 1987)

\begin{abstract}
The kinetic analyses for evaluation of the uptake and decomposition of pesticides by algae were pursued by using the green alga Selenastrum capricornutum and organophosphorus insecticides. The alga-induced disappearance rate constants $\left(k_{\mathrm{A}}\right)$ of fenitrothion, diazinon and cyanophos in each exponential growth stage, steady stage and whole growth period of algae were estimated independently of other disappearance rate constants originated from light and medium ( $k_{\nu}$ and $k_{\mathrm{M}}$, respectively). The $k_{\mathrm{A}}$ values in the steady stage were 1.3-2.5 times larger than those in the exponential growth stage in all chemicals. The $k_{\mathrm{A}}$ values during the whole growth period were between those in the exponential growth stage and those in the steady stage, being closer to those in the steady stage. The $k_{\nu}$ and $k_{\mathrm{M}}$ values were also estimated for comparison in contribution for the disappearance.
\end{abstract}

\section{INTRODUCTION}

In the aquatic environment, algae play not only a vital role as primary producers but also another important role as scavengers for some polluting chemicals. ${ }^{1-3)}$ However, enough information on the uptake and decomposition of chemicals by algae is not available, while many investigations on the effects of pesticides against algae $\left.{ }^{4}\right)$ have been done.

It is not always easy to determine the disappearance rates of pesticides by algae independently of other factors, due to the difficulty in applying kinetic analyses as algae show a characteristic growth pattern under light. The analyses, therefore, were obliged to apply on experimental results under limited conditions, such as a short period in which the algal growth could be ignored and a steady stage in which the algal growth apparently stopped. For this reason, the parameters obtained under such limited conditions may differ from the average values during the whole growth period.

Laboratory experiments were conducted to kinetically evaluate the alga-induced disap- pearance of pesticides in aquatic media. The present paper proposes a kinetic model and the analytical equations including algal growth equations. The green alga, Selenastrum capricornutum, and representative organophosphorus insecticides, fenitrothion, diazinon and cyanophos, were used for the experiments. The kinetic analyses were applied to each of the exponential growth stage, steady stage and whole growth period of algae.

\section{MATERIALS AND METHODS}

\section{1. $A \lg a$}

The green alga, Selenastrum capricornutum, one of the standard species for the evaluation of algal growth potential, was supplied from the Environmental Chemical Analysis Center of Shimane University. The alga was precultured at $20^{\circ} \mathrm{C}$ in sterilized Bold's basal medium $^{5)}$ buffered at $\mathrm{pH} 6.7$ under continuous illumination at 4000 lux (fluorescent light, NATIONAL Homolux ${ }^{\circledR}$, FL 20S·PG) with reciprocal shaking (MONOSHIN ${ }^{\circledR}$-II, TAIYO KAGAKU, 60 strokes/min). The algal growth was measured by counting the cell number with 
a haemacytometer.

\section{Chemicals}

Fenitrothion (O,O-dimethyl O-3-methyl-4nitrophenyl phosphorothioate, $96.3 \%$, Sumitomo Chemical Co., Ltd.), diazinon $(O, O$-diethyl O-2-isopropyl-6-methyl-pyrimidin-4-yl phosphorothioate, $96.5 \%$, Nippon Kayaku Co., Ltd.) and cyanophos $(O, O$-dimethyl $O$-4-cyanophenyl phosphorothioate, $95.0 \%$, Sumitomo Chemical Co., Ltd.), all technical grade, were donated by the manufacturers and were used without purifying.

\section{Study on Disappearance Rate}

The disappearance rates of the three chemicals were determined in the presence of $S$. capricornutum. To $75.0 \mathrm{ml}$ of sterilized Bold's basal medium buffered at $\mathrm{pH} 6.7$ in a $100-\mathrm{ml}$ Erlenmeyer flask, $5.0 \mathrm{ml}$ of the pre-cultured $S$. capricornutum at the exponential growth stage and $0.5 \mathrm{ml}$ of acetone solution containing 75 ppm of each chemical were added under sterile conditions. The flask was stoppered with a sterile silicone-gum plug and was incubated at $20^{\circ} \mathrm{C}$ under continuous illumination at 4000 lux with reciprocal shaking. As a control, a medium in the absence of $S$. capricornutum was incubated at $20^{\circ} \mathrm{C}$, under both continuous illumination and dark conditions with reciprocal shaking. A $5.0 \mathrm{ml}$ portion of each incubating solution was pipetted out at an appropriate interval to count the algal cell number and to determine the residual amounts of three chemicals. The $\mathrm{pH}$ constancy in each medium was confirmed after the final sampling.

\section{Determination of Chemicals}

To $5.0 \mathrm{ml}$ of the sampled solution, $20 \mathrm{ml}$ of $10 \% \mathrm{NaCl}$ aqueous solution was added and extracted with three 25-ml portions of $\mathrm{CH}_{2} \mathrm{Cl}_{2}$. The $\mathrm{CH}_{2} \mathrm{Cl}_{2}$ layers were combined, dried over anhydrous $\mathrm{Na}_{2} \mathrm{SO}_{4}$ and evaporated just to dryness. To the residue, an appropriate amount of $3.5 \mathrm{ppm}$ propaphos acetone solution was added as an internal standard. The solution was injected into GLC (Shimadzu GC$7 \mathrm{~A})$ equipped with a $\mathrm{FTD}(\mathrm{Rb})$ and the amount of each chemical was determined simultaneously by the peak height ratio method. The GLC conditions: Column; 5\% Silicone DC QF-

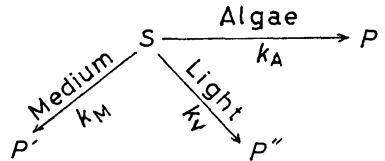

Fig. 1 Kinetic model for the disappearance of chemicals in the cultured medium of algae.

$S$ : chemicals, $P$ : chemicals taken up and decomposed by algae, $P^{\prime}$ and $P^{\prime \prime}$ : decomposed products, $k_{\mathrm{A}}, k_{\nu}$ and $k_{\mathrm{M}}$ : rate constants for the disappearance of chemicals originated from algae, light and medium, respectively.

1 on 60/80 mesh Chromosorb-W HP, $3 \mathrm{~mm} \phi \times$ $1 \mathrm{~m}$, glass column. Temperature; column $210^{\circ} \mathrm{C}$, injection $\&$ detector $270^{\circ} \mathrm{C}$. Gas flow; $\mathrm{He}$ (carrier gas) $30, \mathrm{H}_{2} 3.5$, air $150 \mathrm{ml} / \mathrm{min}$. The recoveries and minimum detectable levels of three chemicals in these conditions were more than $92.0 \%$ at $0.5 \mathrm{ppm}$ and approximately $0.02 \mathrm{ppm}$, respectively.

\section{KINETIC MODEL AND ANALYTICAL PROCEDURE}

The kinetic model for the disappearance of chemicals in the cultured medium of algae is shown in Fig. 1, in which $P$ means chemicals adsorbed, absorbed and/or decomposed by algae, and $P^{\prime}$ and $P^{\prime \prime}$ mean products decomposed by other factors, $\mathrm{pH}$ in the medium and light irradiation, respectively. According to this model in which concentrations of a chemical and algae were expressed by $[S]$ and $X$, respectively, the disappearance rate of the chemical in the medium was

$$
\begin{aligned}
-d[S] / d t & =\left(k_{\mathrm{M}}+k_{\nu}+k_{\mathrm{A}} \cdot X\right)[S] \\
& =\left(k_{0}+k_{\mathrm{A}} \cdot X\right)[S]
\end{aligned}
$$

where $k_{0}=k_{\mathrm{M}}+k_{\nu}$.

Here, it became important that the $X$ value was approximated by some other equations. In this study, the kinetic analyses were applied to each of the exponential growth stage, the steady stage and the whole period of algal growth. In each stage, $X$ was approximated as follows:

1) The exponential growth stage;

$$
\begin{aligned}
& d X / d t=C \cdot X \\
& \quad \therefore \quad X=\exp [A+C \cdot t]
\end{aligned}
$$

2) The steady stage;

$$
d X / d t=0 \quad \therefore \quad X=B
$$


3) The whole growth period;

a) Mitscherlich equation;

$$
\begin{aligned}
& d X \mid d t=C(B-X) \\
& \quad \therefore \quad X=B(1-\exp [A-C \cdot t])
\end{aligned}
$$

b) Logistic equation;

$$
\begin{aligned}
& d X / d t=C / B \cdot X(B-X) \\
& \quad \therefore \quad X=B /(1+\exp [A-C \cdot t])
\end{aligned}
$$

where $t$ was time, $X$ the algal concentration at $t, A$ the constant concerning the growth initiation, $B$ the upper limit of algal growth, and $C$ the growth rate constant. Mitscherlich and Logistic equations are known as the growth equation of biota. ${ }^{6,7)}$

By substituting above Eqs. (3)-(6) for $X$ in Eq. (2) and solving each equation, the following relationship between the concentration of the chemical and $t$ was obtained:

1) The exponential growth stage;

$$
\ln [S] /[S]_{0}=-k_{0} t+k_{\mathrm{A}} \cdot e^{A}\left(1-e^{C . t}\right) / C
$$

2) The steady stage;

$$
\ln [S] /[S]_{0}=-\left(k_{0}+k_{\mathrm{A}} \cdot B\right) t
$$

3) The whole growth period;

a) Mitscherlich equation;

$$
\begin{array}{r}
\ln [S] /[S]_{0}=-\left(k_{0}+k_{\mathrm{A}} \cdot B\right) t \\
+k_{\mathrm{A}} \cdot B \cdot e^{A}\left(1-e^{-C . t}\right) / C
\end{array}
$$

b) Logistic equation;

$$
\begin{aligned}
\ln [S] /[S]_{0}=-k_{0} t-k_{\mathrm{A}} \cdot B \\
\cdot \ln \left[\left(e^{A}+e^{\sigma . t}\right) /\left(e^{A}+1\right)\right] / C
\end{aligned}
$$

where $[S]_{0}$ was the concentration of the chemical at $t=0$.

Here, the accurate evaluation of $k_{0}$ may be difficult in a strict sense, because the presence of algae affects the transmittance of light. In this study, however, $k_{0}$ was substituted with the decomposition rate constant of each chemical in the control under continuous illumination in the absence of algae. It means that the maximum value of $k_{0}$ was adopted. The values of $A, B$ and $C$ can be estimated from the algal growth curves in the presence of the chemical. Therefore, by analyzing the relationship between the residual amount of the chemical and $t$ according to the Eqs. (7)-(10), the disappearance rate constant $k_{\mathrm{A}}$ originated from algae can be obtained: Furthermore, $k_{\mathrm{M}}$ can be estimated from the residual amount of the chemical in the control under dark conditions in the absence of algae, and $k_{\nu}$ is calculated by $k_{0}=$
$k_{\mathrm{M}}+k_{\nu}$.

All analyses were carried out by using a microcomputer (NEC.PC-8001 MK-II).

\section{RESULTS AND DISCUSSION}

The disappearance rates of pesticides were studied by using the green alga Selenastrum capricornutum to which fenitrothion, diazinon and cyanophos were added simultaneously at concentrations sufficient enough to make determination easier without affecting the algal growth. The growth of S. capricornutum were similar in the presence and in the absence of each $0.47 \mathrm{ppm}$ of fenitrothion, diazinon and cyanophos, as shown in Fig. 2. The growth parameters $(A, B$ and $C)$ for analyses of the disappearance rates were calculated from the growth rate in the presence of the chemicals. The values obtained are summarized in Table 1. The growth curves by Eqs. (3)-(6) were computed based on these parameters and shown in Figs. 3 and 2, respectively. S. capricornutum changed from the exponential growth stage to the steady stage within approximately 7.5 days in this condition and the change was satisfactorily followed by the growth curves based on Eqs. (3) and (4) as shown in Fig. 3. Moreover, the growth curves based on Eqs. (5) and (6) for the whole period (Figs. 3 and 2) seemed to be

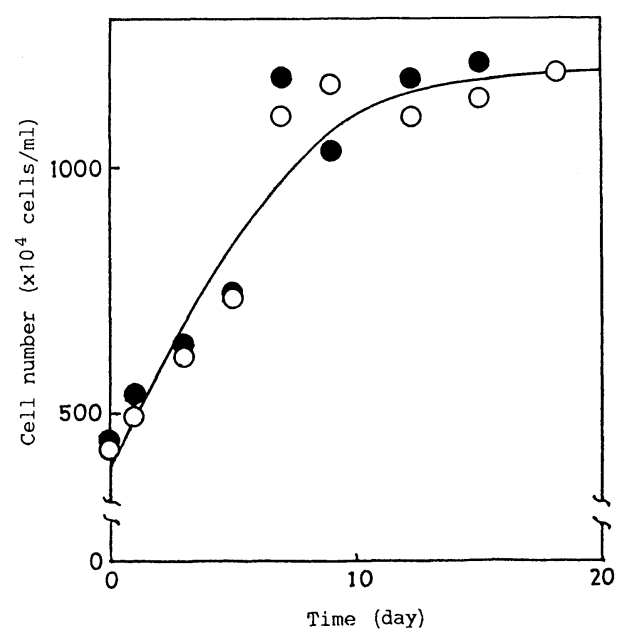

Fig. 2 Growth curve (1) of S. capricornutum.

-: in the absence of chemicals, $\bigcirc:$ in the presence of chemicals. The growth curve illustrated is based on Eq. (6). 
Table 1 Growth parameters for S. capricornutum.

\begin{tabular}{|c|c|c|c|c|}
\hline \multirow[b]{2}{*}{ Parameter } & \multirow{2}{*}{$\begin{array}{c}\text { Exponential } \\
\text { growth stage } \\
\text { Eq. (3) }\end{array}$} & \multirow{2}{*}{$\begin{array}{l}\text { Steady stage } \\
\text { Eq. (4) }\end{array}$} & \multicolumn{2}{|c|}{ Whole growth period } \\
\hline & & & $\begin{array}{l}\text { Mitscherlich Eq. } \\
\text { Eq. (5) }\end{array}$ & $\begin{array}{l}\text { Logistic Eq. } \\
\text { Eq. (6) }\end{array}$ \\
\hline$A$ & 15.2301 & - & -0.35236 & 0.75385 \\
\hline$B($ cell $/ \mathrm{ml})$ & - & $1.153 \times 10^{7}$ & $1.26581 \times 10^{7}$ & $1.19646 \times 10^{7}$ \\
\hline$C\left(\right.$ day $\left.^{-1}\right)$ & 0.13637 & - & 0.15694 & 0.33432 \\
\hline
\end{tabular}

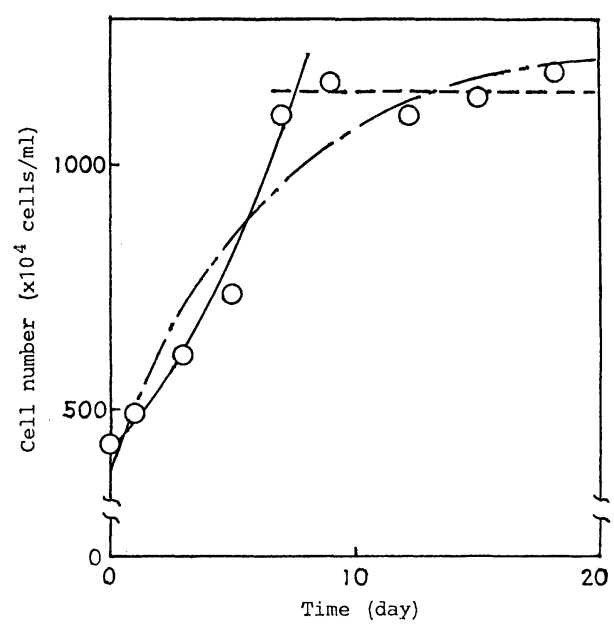

Fig. 3 Growth curves (2) of $S$. capricornutum. $O:$ in the presence of chemicals. The growth curves illustrated are based on Eq. (3) Eq. (4) -..- and Eq. (5) _- _, respectively.

practically suitable, although there were differences at the last stage of exponential growth and the early steady stage.

The disappearance of fenitrothion, diazinon and cyanophos from the medium through the whole growth period is shown in Fig. 4. The disappearance of the chemicals in the absence of $S$. capricornutum was very small, as the case of fenitrothion shows in Fig. 4. It was clear that the disappearance of the chemicals was promoted by algae and accerelated as they grew.

The rate constant $k_{\mathrm{A}}$ for the disappearance caused by $S$. capricornutum was calculated by using Eqs. (7)-(10). The rate constant $k_{0}$ was obtained by analyzing the disappearance rates of the chemicals in the control under continuous illumination in the absence of alga. It obeyed good first-order kinetics. The rate con-

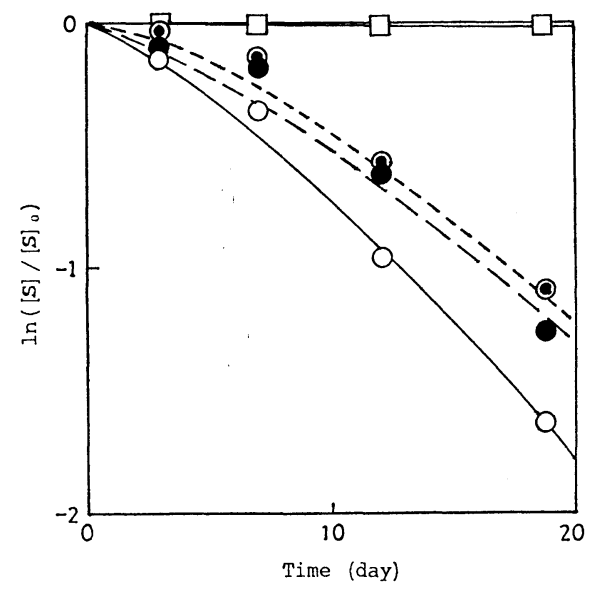

Fig. 4 Disappearance curves of chemicals in the presence of S. capricornutum.

$\bigcirc$ : Fenitrothion, ๑: Diazinon, ๑: Cyanophos. Control in the absence of $S$. capricornutum, $\square$ : Fenitrothion.

stant $k_{\mathrm{M}}$ originated from the medium was obtained by analyzing the first-order disappearance of the chemicals in the control under dark condition in the absence of alga and the rate constant $k_{\nu}$ originated from light was calculated by $k_{\nu}=k_{0}-k_{\mathrm{M}}$. The values obtained are summarized in Table 2.

In the disappearance of the chemicals caused by $S$. capricornutum, $k_{\mathrm{A}}$ values in the steady stage were larger than those in the exponential growth stage in all the chemicals; the ratio of the former to the latter ranged from $c a .1 .3$ in fenitrothion to $c a .2 .5$ in diazinon and cyanophos. It was obvious that the uptake and decomposition of the chemicals differed in each stage of algae. On the other hand, $k_{\mathrm{A}}$ values for the whole period obtained by Eqs. (9) and (10) were nearly coincidental; the values were between those for the exponential stage and 
Table 2 Rate constants for factors related to the disappearance of chemicals in the cultured medium.

\begin{tabular}{|c|c|c|c|c|c|}
\hline Parameter & \multicolumn{2}{|c|}{ Growth stage } & Fenitrothion & Diazinon & Cyanophos \\
\hline \multirow{5}{*}{$k_{\mathrm{A}}$} & & & \multicolumn{3}{|c|}{$\times 10^{-9}(\mathrm{cell} / \mathrm{ml})^{-1} \mathrm{day}^{-1}$} \\
\hline & Exp. growth stage & Eq. (7) & 6.62795 & 3.12473 & 2.61686 \\
\hline & Steady stage & Eq. (8) & 8.36414 & 7.71321 & 6.87487 \\
\hline & \multirow{2}{*}{ Whole growth period } & Eq. (9) & 8.22557 & 5.76504 & 5.51344 \\
\hline & & Eq. (10) & 8.70985 & 5.77164 & 5.52064 \\
\hline & & & \multicolumn{3}{|c|}{$\times 10^{-3} \mathrm{day}^{-1}$} \\
\hline$k_{0}$ & & & 5.6748 & 6.2664 & 1.2336 \\
\hline$k_{\mathrm{M}}$ & & & 1.8288 & 3.1200 & 0.4848 \\
\hline$k_{\nu}$ & & & 3.8496 & 3.1464 & 0.7488 \\
\hline
\end{tabular}

Table 3 Contribution ratio of each factor for the disappearance of chemicals in the steady stage.

\begin{tabular}{lccc}
\hline \multirow{2}{*}{ Factor } & \multicolumn{3}{c}{ Contribution ratio (\%) } \\
\cline { 2 - 4 } & $\begin{array}{c}\text { Fenitro- } \\
\text { thion }\end{array}$ & Diazinon & Cyanophos \\
\hline Algae $^{\text {a) }}$ & 92.9 & 85.0 & 96.0 \\
$\begin{array}{l}\text { Light } \\
\text { (Illumination) }\end{array}$ & 4.8 & 7.5 & 2.4 \\
Medium & 2.3 & 7.5 & 1.6 \\
\hline a) Calculated by using $1.153 \times 10^{7}$ cell $/ \mathrm{ml}$ as the \\
$\quad \begin{array}{l}\text { algal concentration (Table } \\
\text { from Eq. (8) in Table } 2 .\end{array}$ & and $k_{\mathrm{A}}$ values \\
\end{tabular}

those for the steady stage, being closer those for the steady stage. The disappearance curves of the three chemicals computed by using Eq. (10) and the parameters in Table 2 are shown in Fig. 4. The curves were practically suitable, although there were differences in the exponential growth stage.

Limiting to the steady stage, the contribution ratios of alga, light and medium for the disappearance of the chemicals could be estimated by using $X$ in Eq. (4), $k_{\mathrm{A}}$ in Eq. (8), and $k_{\nu}$ and $k_{\mathrm{M}}$ in Table 2. The ratios estimated are shown in Table 3. In these experimental conditions, the alga was the major factor. In natural conditions, however, the contribution of sunlight would be greater.

Kikuchi et $a l .^{3)}$ reported the behavior of fenitrothion in three species of algae, saying that fenitrothion was rapidly absorbed from a medium and reached an equilibrium in algae, and then rapidly excreted when the algae were transferred to a fenitrothion-free medium, with half-lives of 1-2.6 hr, and that the metabolic decomposition rates were radically different among the algae. It seems that diazinon and cyanophos would behave similarly in algae. The kinetic rates in this study were represented by the disappearance rates involving the uptake and decomposition of the chemicals since the amounts of the chemicals accumulated in algae were not determined. In the case of fenitrothion and some other organophosphorus insecticides, however, the rates might practically represent the decomposition rates as they rapidly reached an equilibrium.

In this study, the disappearance rate constants for fenitrothion, diazinon and cyanophos in each period of the exponential growth stage and the steady stage and during the whole growth period of $S$. capricornutum were practically estimated independently of other factors by using the kinetic analyses. Further confirmation should follow using other kinds of algae and pesticides, and under more practical conditions.

\section{REFERENCES}

1) R. G. Zepp \& P. F. Schlotzhauer: Environ. Sci. Technol. 17, 462 (1983)

2) M. Fukushima: Ecol. Chem. 6 (2), 4 (1983)

3) R. Kikuchi, T. Yasutaniya, Y. Takimoto, H. Yamada \& J. Miyamoto: J. Pesticide Sci. 9, 331 (1984)

4) G. L. Butler: "Residue Reviews," ed. by F. A. Gunther, Vol. 66, Springer-Verlag, New York, pp. 19-61, 1977

5) H. C. Bold: Ann. New York Acad. Sci. 175, 601 (1970)

6) F. J. Richards: J. Exp. Bot. 10 (29), 290 (1959) 
7) M. Yamamoto, H. Yasui \& F. Akiyama: Bull. Fac. Agric. Shimane Univ. 16, 48 (1982)

要約

藻類による農薬の吸収・分解能の動力学的解 析 (1)

中村利家, 持田和男

藻類に起因する農薬の吸収と分解の動力学的解析・評 価を, 緑藻の Selenastrum capricornutum および有機り ン系殺虫戍を用いて検討した. 藻類の対数増殖期, 定常、
状態期および全増殖域について, fenitrothion, diazinon 扣よび cyanophos の藻類に起因する消失速度定数 $\left(k_{\mathrm{A}}\right)$ を，他の光和よび培地に起因する消失速度定数（それぞ

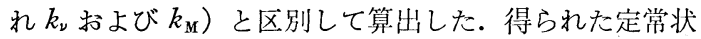
態期に対する $k_{\mathrm{A}}$ 值は, いずれの化合物でも対数堌殖期 に対する $k_{\mathrm{A}}$ 值より大きく, fenitrothion で約 1.3 倍, diazinon と cyanophos で約 2.5 倍の差があった. 全増殖域 に対する $k_{\mathrm{A}}$ 值はその中間で, 前者に近い值であった. $k_{\nu}$ および $k_{\mathrm{M}}$ 值も算出し, 定常状態期に達した後の各消 失要因の寄与率の比較も試みた。 